\title{
Sports and Nature Conservation - Ten Theses on the Optimisation of Shared Communication
}

\author{
Maik Adomßent* \\ Institute for Environmental and Sustainability Communication INFU, Leuphana University Lüneburg, Germany
}

\begin{abstract}
In the classical understanding of environmental policy, environmental communication is commonly considered a persuasive (or informational or appellative) instrument. As a result, its importance is often underestimated and it is classified as a 'soft' instrument, although it has a central function in terms of implementation and acceptance of other instruments. This contribution aims to highlight different levels and elements of communication that are particularly relevant in the context of sports and nature conservation. In this article the potential for optimization in this area will be described succinctly in the form of ten theses, supported by both positive and negative examples from a collection of material on this topic. An analytical framework relates the ten theses to different observation levels and phases of the communicative context. Furthermore, potential spaces for developing strategic options for communication in the field of sports and nature conservation that have been neglected until now.
\end{abstract}

Keywords: Sportification; Sports and nature conservation; Optimisation

\section{Introduction}

Sports in their modern form began, according to Weis and Gugutzer in the mid-nineteenth century [1]. Over time, non-athletic and noncompetitive sports came to be recognized as sports, leading to a general "sportification" of society and everyday life, with sports being not just a product but also a motor of societal individualization processes [2]. Sports thus function as a cross-cultural medium of communication and contribute to the integration of individuals in society, as do few other social fields of action including nature conservation.

When studying societal processes of communication between sports and nature conservation against the backdrop of sustainable development, it is instructive to focus on the communicative interplay of the individual and society together with mediatory agencies $[3,4]$. As a regulatory idea, the implementation of the sustainability vision is essentially about making society capable of learning and taking action at all of its levels- from ecological to economic and especially social and cultural, and so also the conservation of nature.

On the individual level the focus is on the development of new knowledge and new competencies that enable a person to act sustainably, whereas on the institutional level (in particular educational institutions as well as sports associations or political parties) it is about setting new priorities and the continuous improvement of the quality and performance of sustainability related structures. Ultimately, what is necessary is the creation of new agendas and their implementation with the help of new partnerships, together with new possibilities of interaction and participation [5]. The long-term goal is a learning society that develops towards sustainability in a co-evolutionary interplay of individuals and organizations (Figure 1). Without social communication about sustainability, neither a sustainable society nor sustainable sports will be possible [6] (Figure 1).

However this contribution is not focusing on or highlighting specific models of communication. It is more about trying to strike a new path by generalizing and compacting empirical findings, sometimes taking things to the extreme in a slightly provocative way.

\section{Materials and Methods}

For this brief study a great variety of materials on communication in the field of sports and nature conservation were surveyed. Particular emphasis was put on representative studies and due to lack of relevant data from other continents the geographical focus was laid on Europe. By means of "Eurobarometers" a series of public opinion surveys conducted regularly on behalf of the European Commission since 1973,

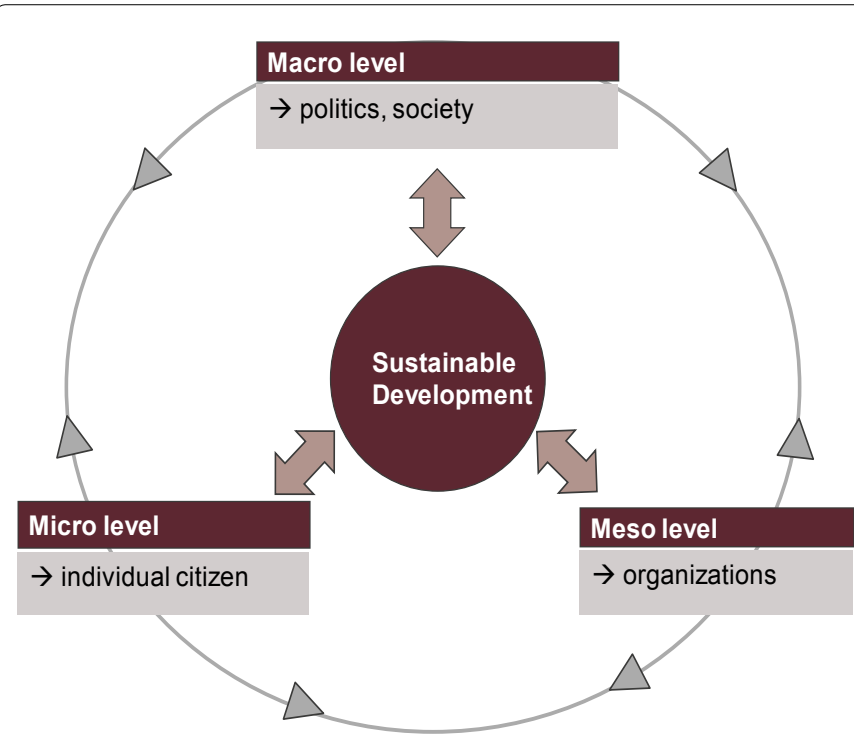

Figure 1: Communication and learning for sustainable development: Coevolutionary interaction in a multi-level system (see also Table 1).

*Corresponding author: Maik Adomßent, Temporary Professor for Behaviour, Communication and Sustainable Development, Institute for Environmental and Sustainability Communication INFU, Leuphana University Lüneburg, Scharnhorststrasse 1, D 21335 Lüneburg, Germany, Tel: 4904131677 2924; Fax: 4904131677 2819; E-mail: adomssent@uni.leuphana.de

Received March 24, 2015; Accepted July 02, 2015; Published July 10, 2015

Citation: Adomßent M, (2015) Sports and Nature Conservation - Ten Theses on the Optimisation of Shared Communication. J Biodivers Biopros Dev 2: 153 doi:10.4172/2376-0214.1000153

Copyright: ( 2015 Adomßent M, This is an open-access article distributed under the terms of the Creative Commons Attribution License, which permits unrestricted use, distribution, and reproduction in any medium, provided the original author and source are credited. 
addressing a wide variety of topical issues relating to the European Union throughout all EU Member States a solid statistical foundations was sought. Selected Eurobarometers of special interest here included sport and physical activity and attitudes towards the environment [7-10]. Wherever possible these surveys have been complemented in recourse to a number of environmental data resources (among them: EarthTrends - the Environmental Information Portal; Socioeconomic Applications and Data Center at Columbia University; United Nations Environmental Programme Data Portal; World Bank Environment). Finally, a couple of significant nationwide surveys added to the data base, e.g. two-year nature awareness studies from Germany, a Swiss survey on attitudes towards wilderness and public demands on wilderness [11-14].

Along with printed media such as guidelines, conference documentation, hand-outs, journal articles, news media (e.g. the information service "Sports Protects the Environment" from the DOSB - German Olympic Sports Confederation) and training material, the webpages of selected associations and institutions (e.g. "Nature Sports Info" from BfN - German Federal Agency for Nature Conservation, and BAFU - Swiss Federal Office for the Environment) were also examined more closely. This material was analyzed using a matrix according to observation levels and communication phases in order to systematize its communication content [15].

The goal was not to undertake a comprehensive survey or a systematic qualitative content analysis. Instead, an overview of different aspects such as topic preparation, target group specificity, word choice etc. are condensed into theses that show the potential for optimizing communication in the field of sports and nature conservation (Table $1)$.

The following theses are illustrated, where possible, with positive and negative examples.

\section{Results and Discussion}

Thesis 1 The communication of content (primarily from a nature conservation perspective) is often one-dimensional and fails to adequately address target groups, thus reducing the probability of bringing about behavioral changes.

Communication about nature conservation should work towards raising awareness and behavioral change. However, most often the messages appeal at a cognitive level, although behavioral research in environmental psychology has repeatedly shown that knowledge has a minimal and at most indirect influence on behavior [16].

A well-understood balance between emotion, motivation and cognition is also missing from target group strategy [17]. Since the contents and forms of communication tend to be embedded in a network of self-understandings and behavioral dispositions, in nature conservation these would often be based on the natural sciences, which would then be reflected in the patterns of argumentation used [18].

Persons who take part in sports should thus be appealed to as laypersons in nature conservation while taking their individual differences into account, in particular gender-specific differentiation as well as age-dependent preferences. A good example of target group strategy in communication can be found in the hand-out "Biotope management on golf courses" (BfN and DGV 2005), which has created a balance between informative text and emotional images to motivate the targeted readership to take matters in hand and strive for change.

Thesis 2 The potential of informal communication in informal contexts has not been sufficiently recognized.

Generally speaking, informal learning is taken to mean unregulated learning that happens as a result of life experiences, with communicative processes playing an important role [19]. Furthermore, the learning environment has a fundamental importance. With regard to the communication initiatives in this study, it should be noted that adult learning mainly occurs during leisure time where factors such as self-determination, self-initiated activities and freedom play a central role [20]. Accordingly, informal communication, provided it is carefully designed, offers favorable conditions for positive educational outcomes.

However, informal education during vacation and leisure time has been so far strongly neglected in Germany, in contrast to nature conservation efforts in the United States [21]. It was first in 2004 that a EUROPARC certificate for the interpretation of protected natural and cultural landscapes was introduced. This certificate is now being reviewed to ensure that it meets current needs, including those of education for sustainable development (www.parcinterp.de). It would be a logical step to target nature sports, not least because they are often non-organized and so there is a corresponding lack of opportunity to target the people participating in them through sports clubs and associations.

Thesis 3 Cooperation among associations in sports and in nature conservation is important, but should be based on achieving resultsoriented goals.

Given the social representative function that both sports and nature conservation associations play it would only be logical for them to work jointly on solutions to emerging conflicts [22,23]. An example for this is the "Wiesbaden Declaration" from the German League for Nature, Animal Protection and Environment (DNR) and the German Sports Confederation (DSB) on principles for sports to be compatible with the conservation of natural and cultural environments [24]. Lower Saxony seems to lag behind in this respect, as cooperation between its

\begin{tabular}{|c|c|c|}
\hline Phase level & $\begin{array}{c}\text { Input/Context } \\
\text { e.g. social and political framework } \\
\text { conditions }\end{array}$ & $\begin{array}{c}\text { Output/Outcome } \\
\text { e.g. function of support systems, } \\
\text { forms of anchoring }\end{array}$ \\
\hline $\begin{array}{c}\text { Macro-level (society) } \\
\text { of competencies, changing of system } \\
\text { functions }\end{array}$ & Transfer mechanisms [9] \\
\hline $\begin{array}{c}\text { Meso-level (organizations) } \\
\text { e.g. nature conservation and sports } \\
\text { associations, political parties }\end{array}$ & $\begin{array}{c}\text { Strategic motivation alliances [4] } \\
\text { Mass media [10] }\end{array}$ & $\begin{array}{c}\text { Cooperation among associations [3] } \\
\text { Resource communication [5] }\end{array}$ \\
\hline $\begin{array}{c}\text { Micro-level (individuals/small groups) } \\
\text { e.g. individual communication measures }\end{array}$ & Target group strategy [1] & Informal communication [2] \\
\hline
\end{tabular}

Table 1: Analytical framework for classifying the theses in observation levels and communication phases (own diagram; based on indicator-based heuristic in educational reporting; cf. Konsortium 2005; BMBF 2004, BMBF 2003; Konsortium 2006; Autorengruppe 2008). 
environmental ministry and sports confederation has so far brought forth little of value [25].

Cooperation among associations, on the other hand, has been productive in other areas. The work between the German Aero Club and the Federal Agency for Nature Conservation has resulted in a training module for pilots entitled "Aviation and Nature Conservation" [26]. A similar outcome was achieved with "Training Guidelines for Multipliers" produced by the German Youth Sports in the German Olympic Sports Confederation and the Youth Association for the Protection of Nature.

Thesis 4 Greater attention should be paid to strategic motivation alliances in communication at the interface between nature conservation and sports. The principles of sustainable development serve as a suitable search corridor.

In their standard work Schemel and Erbguth transfer the principles of sustainable development to the relationship between sports and the environment to create a principle of "sustainable sports practice" (ibid: 19f.) [27]. The multiple dimensions of sustainability reveal potential synergies that have not yet been recognized or have been so far insufficiently used [17].

It is worth looking more closely here at an example concerning health because the perspectives of communication strategy reveal possible motivation alliances. In this case participants combine an orientation to physical health and fitness with an orientation to nature as motivation for their practice of sports (Claßen et al. 2005). For example, the brochure "Nature Moves - Nature Sports in Germany" (BMU 2006) is advertised as promoting "experience, health and wellbeing." Just how these three elements are to be put into practice in sensitive and often protected natural areas requires however more initiative and creative input on the side of nature conservation. In many cases there is a lack of "courage to provide low-threshold offerings that are suitable for both 'non-birdwatchers' and 'anti-sportspeople' and take place in nature" [28].

Thesis 5 In communication between nature conservation and sports the dominant scenarios are of conflict and should be replaced by constructive resource communication.

Much published material at the interface between sports and nature conservation refers one-sidedly to real or potential conflict. For example, on the back cover of "Sports and the Environment" the work is promoted by specifying how it deals with "conflict relationships" and provides "solution methods." Furthermore, "it demonstrates from the perspectives of the environment and sports where the goals are complementary and where there are starting points for concerted action" [27]. While doubtlessly the relationship between nature conservation and sports can hardly be free from tension, simply by emphasizing the possibility of finding solutions would help avoid the impression that this relationship is marked by permanent conflict.

What is thus needed is a form of communication that takes each and every actor seriously by appreciating their knowledge and competencies as possible resources that can contribute to problem-solving - also when this involves conflict [29]. How resource communication can be used to shift this emphasis to be more constructive can be found in the NATURA 2000 guideline for "Sports and Nature", which emphasizes "consequences and opportunities" and shows "pathways to cooperative solutions" [30].

Thesis 6 Both individuals and society should define the competencies needed so that the principle of responsible decisionmaking and action can serve as an ethical foundation for the sustainable practice of sports.

As part of an "environment-related sports ethics," Meinberg calls for putting next to the principle of the protection and conservation of the natural environment that of sustainable development [31]. Together with the optimistic assumption "that just as every relation to nature is socially determined and so politically changeable", so too is every action in sports related to society and thus no less changeable" the principle of changeability is thus critical for a future-oriented development of the relationship between sports and the environment [32].

The concept of gestaltungskompetenz (shaping competence) in terms of education for sustainable development (ESD) is relevant here. This concept refers to the set of competences needed to recognize non-sustainable development and then apply knowledge and skills to move towards more sustainable development [33]. Many of these competences are communicative in nature (Table 2).

Thesis 7 Due to insufficient evaluation there is a lack of empirical knowledge about the effectiveness of communication approaches and strategies in nature conservation

There is significantly less systematic study of the effectiveness of communicative approaches and strategies than of nature conservation measures in the area of environmental planning. Generally speaking, evaluation is about - regardless of the media used or the contents being

\begin{tabular}{|c|r|}
\hline Classic concepts of competence & $\begin{array}{c}\text { Sub-competences of gestaltungskompetenz } \\
\text { dimension }\end{array}$ \\
\hline \multirow{3}{*}{ Professional competences } & Being open-minded and able to develop new knowledge by integrating different perspectives \\
\cline { 2 - 3 } & Being able to anticipate, analyze and evaluate developments \\
\cline { 2 - 3 } & Being able to acquire interdisciplinary knowledge and take action \\
\hline \multirow{2}{*}{ Social competences } & Being able to plan and act together with others \\
\hline \multirow{3}{*}{ Self-competences } & Being able to participate in collective decision-making processes \\
\hline & Being able to motivate oneself and others to take action \\
\hline & Being able to allow for goal conflicts when reflecting on strategies to take action \\
\hline & Being able to reflect on one's own visions and those of others \\
\hline & Being able to plan and take action independently \\
\hline
\end{tabular}

Table 2: Sub-competences of ESD in terms of the gestaltungskompetenz model (de Haan [33]). 
communicated - making processes transparent, documenting impacts and demonstrating relationships in order to improve the quality of a program or measure [34]. In spite of the great number of different creative projects, given the insufficient use or complete lack of quality assurance monitoring, there is a danger of continually having to reinvent the wheel.

For example, in the opinion of the author and others, the toolbox developed as part of the project "Sports activities in harmony with nature and landscape - Action-oriented solutions for the practice" [35] still awaits review as to whether its goals have been achieved or not. It would be interesting to know, for example, to what extent the toolbox has been able to in particular "raise the awareness of athletes and those pursuing athletic activities in their free time that are not organized in clubs or associations" [36].

Thesis 8 Innovative approaches to research at the interface between communication and nature conservation need to specify their applicability to practice.

There are also deficits regarding research itself. For example, the broad empirical basis to studies on lifestyles and acceptance gives a certain initial plausibility to their recommendations for nature conservation campaigns. However, to date there has been no evaluation of these research findings regarding their practicability. Yet this is the only way to determine whether campaigns can be adequately targeted at specific and possibly problematic lifestyle groups and, more importantly, whether they can lead to the desired effects. This is also encouraged by one of the authors of this study "in order to be able to develop dialogic and persuasive communication channels" [37,38].

Thesis 9 There are too few initiatives and/or opportunities for bundling and transferring practical research findings to communicative practice in nature conservation.

Building on the eighth thesis, there is a lack of transfer of research findings in practical work in nature conservation. This is the responsibility of institutions sponsoring research, which should include a funding requirement that when communication concepts and instruments are developed their practicability is also evaluated. At the same time efforts should be made so that research findings include concrete steps detailing their implementation, as otherwise the potential of the research could be insufficiently or not at all used in practice.

Research institutions should also require publications to have a greater practice orientation. To this end, conference report summaries or edited volumes are also useful, as for example the concluding chapter "Basic Information for Implementation" in the brochure "Nature Sport and Communication" [39].

Thesis 10 For communication at the interface between sports and nature conservation, greater use of mass media should be used to reach a broad public.

Many publications revolve around the thesis that topics in nature protection can only be poorly communicated in mass media [40]. But the TV feature "Eurosport For The Planet" shown by the sports channel Eurosport demonstrated that it is also possible to produce programs in television that "address ... current environmental issues, such as the environmental policies of sports associations and the attitudes athletes have towards environmental protection" [41].
An ambitious consortium of partner institutions could search for ways to reach active participants in sports with information about nature conservation through mass media communication channels. The testing and careful evaluation of targetting sports participants - similar to the annual BfN nature sports campaign "Naturathlon" (without, except in 2008, a national media partner; www.naturathlon. de) - would certainly be worth trying.

\section{Conclusions}

Environmental communication has become a part of everyday communication. The discussion of the varied types of private, professional or social perception and processing of complex environmental problems influences the public perception of the environment and nature consumptive activities like sports. Since communication is neither defined by consensus or conflict the ten theses formulated in this contribution are aiming to open up potential spaces for developing strategic options for communication in the field of sports and nature conservation.

According to this direction of impact, communication is not simply a social phenomenon to be observed. It can and, this is what the ten theses on the optimisation of shared communication between sports and nature conservation suggest, also should be strategically influenced. Doubtlessly it is an important instrument of environmental policy, which however should not only be seen as an element of government policy. In fact it can be understood as the sum of all efforts undertaken to develop society ecologically and sustainably.

\section{References}

1. Weis, Gugutzer R/Hrsg (2008) Handbuch Sportsoziologie. Hofmann, Schorndorf $402 \mathrm{~S}$.

2. Rittner V (2000) Ist alles möglich? Gesellschaft im Wandel. In: DSB (Hrsg) Trends im Sport. Dokumentation des 7. Symposiums zur ökologischen Zukunft des Sports vom 23-24 September 1999 in Bodenheim/Rhein: 9-24.

3. Adomßent M, Godemann J (2011) Sustainability communication: an integrative approach In: Godemann J, Michelsen G (eds) Sustainability Communication: Interdisciplinary Perspectives and Theoretical Foundations. Dordrecht: Springer 27-38.

4. Manfredo MJ (2008) Who Cares About Wildlife? Social Science Concepts for Exploring Human-Wildlife Relationships and Conservation Issues. New York: Springer.

5. Goldstein W (2005) Education for sustainable development emerging. ZEP/ Zeitschrift für internationale Bildungsforschung und Entwicklungspädagogik 28 $2-8$

6. Godemann J, Michelsen G (2011) Sustainability Communication: Interdisciplinary Perspectives and Theoretical Foundations. Dordrecht ua: Springer.

7. EU (European Union) (2010) Sport and Physical Activity. Special Eurobarometer 334.

8. EU (European Union) (2014) Sport and Physical Activity. Special Eurobarometer 412.

9. EU (European Union) (2005) The attitudes of European citizens towards environment. Special Eurobarometer 217.

10. EU (European Union) (2011) The attitudes of European citizens towards environment. Special Eurobarometer 365.

11. BMUB (Federal Ministry for the Environment, Nature Conservation, Building and Nuclear Safety) BfN (Federal Agency for Nature Conservation) (2010) Naturbewusstsein 2009. Bevölkerungsumfrage zu natur und biologischer Vielfalt, Berlin and Bonn

12. BMUB, BfN (2012) 2011 Nature Awareness Study. Population survey on nature and biological diversity. Berlin and Bonn. 
Citation: Adomßent M, (2015) Sports and Nature Conservation - Ten Theses on the Optimisation of Shared Communication. J Biodivers Biopros Dev 2: 153. doi:10.4172/2376-0214.1000153

Page 5 of 5

13. BMUB, BfN (2014) 2013 Nature Awareness Study. Population survey on nature and biological diversity. Berlin and Bonn.

14. Bauer N (2005) Attitudes towards Wilderness and Public Demands on Wilderness Areas. Wild Urban Woodlands pp: 47-66.

15. Flick, U (2007) Designing Qualitative Research Sage.

16. Rientjes S (2000) Communication nature conservation. A manual on using communication in support of nature conservation policy and action. Tilburg: ECNC-European Centre for Nature Conservation.

17. Adomßent M (2006) Naturschutzkommunikation -Wege zur gesellschaftlichen Wirksamkeit. In: Erdmann KH, Bork HR, u. Hopf,T(Hrsg) Naturschutz im gesellschaftlichen Kontext. Landwirtschaftsverlag. Münster: 29-53.

18. Schwarzkopf J (2002) Voll abgefahren - Lebensstilbasierte Umweltkommunikation beim Mountainbiking In: DSB (Hrsg) Umweltkommunikation im Sport. Dokumentation des 9. Symposiums zur ökologischen Zukunft des Sports vom 6-7. Dezember 2001 in Bodenheim/ Rhein: 25-40.

19. Dohmen G (2001) Das informelle Lernen. Die internationale Erschließung eine bisher vernachlässigten Grundform menschlichen Lernens für das lebenslange Lernen aller, BMBF-Bonn.

20. Overwien B (2009) Informelles Lernen, Definitionen und Forschungsansätze. In: Brodowski M, Devers Kanoglu U, Overwien B, Rohs M, alinger S, et al. (Hrsg) Informelles Lernen und Bildung für eine nachhaltige Entwicklung. Beiträge aus Theorie und Praxis. Barbara Budrich. Opladen: 23-34.

21. Wohlers L (2001) Informelle Umweltbildung am Beispiel deutscher Nationalparke. Shaker, Aachen 232 S.

22. Bastian $O$ (2013) The role of biodiversity in supporting ecosystem services in Natura 2000 sites. Ecological Indicators: 24: 12-22

23. Votsi NEP, Mazaris AD, Kallimanis AS, Pantis JD (2014) Natural quiet: An additional feature reflecting green tourism development in conservation areas of Greece. Tourism Management Perspectives 11, pp10-17.

24. Deutscher Sportbund/DSB u. Deutscher Naturschutzring/DNR/Hrsg. (1997) Leitbilder eines natur- und landschaftsverträglichen Sports. Dokumentation des Kongresses vom 11-13 Oktober 1996 im Schloß Biebrich Wiesbaden. Frankfurt/M $112 \mathrm{~S}$.

25. Niedersächsisches Ministerium für Umwelt und Klimaschutz/NMU/Hrsg (2009) Umwelt und Sport Partnerschaft für die Zukunft, Selbstverlag Hannover $92 \mathrm{~S}$.

26. Deutscher Aero Club/DaeC, u Bundesamt für Naturschutz/BfN (2007) Naturschutz für Piloten - natur und umweltbewusst fliegen. Materialien für die Aus- und Weiterbildung CD.

27. Schemel H, Erbguth W (2000) Handbuch Sport und Umwelt: Ziele, Analysen, Bewertungen, Lösungsansätze, Rechtsfragen. Meyer \& Meyer; 3. Aufl Aachen $719 \mathrm{~S}$

28. Gerlach J (2009) Ab nach draußen! Positive Effekte und mögliche Angebotsformen von Bewegung im Freien im Spannungsfeld von Naturschutz und nutz. In: Niedersächsisches Ministerium für Umwelt und Klimaschutz
(Hrsg) Umwelt und Sport - Partnerschaft für die Zukunft. Hannover: 6-13.

29. Wolf, Appel Kummer E (2004) Freiwillige Vereinbarungen Naturschutz Natursport. Ein Leitfaden. BfN-Skripten 106; BMU-Druckerei. Bonn 47S.

30. Bundesamt für Naturschutz/BfN; Universität für Bodenkultur Wien Umweltbundesamt $\mathrm{GmbH}$; Stichting Recreatie u. Deutscher Olympischer Sportbund/DOSB/Hrsg (2009) Natura 2000. Sport und Tourismus. Ein Leitfaden zur Anwendung der Fauna-Flora-Habitat-Richtlinie und der VogelschutzRichtlinie, LV-Druck, Münster-Hiltrup $80 \mathrm{~S}$.

31. Meinberg E (1991) Umwelt ein Problem der Sportethik? LÖLF-Mitteilungen 91 43-46.

32. Digel H (1989) Sport in der Risikogesellschaft - Zum Konflikt zwischen Sport und Umwelt. Informationsdienst Naturschutz Niedersachsen 9: 86-100.

33. de Haan G (2010) The development of ESD-related competencies in supportive institutional frameworks. International Review of Education 56 (2-3) pp. 315328.

34. Meyer Stockmann R (2007) Evaluation von Nachhaltigkeitskommunikation In:Michelsen Gu, Godemann J (Hrsg) Handbuch Nachhaltigkeitskommunikation: Grundlagen und Praxis,Aufl Oekom München 351-362.

35. Stremlow, Pütsch M (2006) NaturSportInfo - Das Informationssystem zu Naturschutz und Natursport im Internet. In: BfN (Hrsg) Natursport und Kommunikation. Tagungsband zum Internationalen Fachseminar, ErlebnisKonsumgut Natur: verehrt - verzehrt. BMU-Druckerei, Bonn Bad Godesberg 40-43.

36. Mönnecke M (2006) Kommunikationsmöglichkeiten Natursport - Naturschutz. In: BfN (Hrsg) Natursport und Kommunikation. Tagungsband zum Internationalen Fachseminar Erlebnis-Konsumgut Natur: verehrt - verzehrt BMU-Druckerei Bonn-Bad Godesberg: 30-33.

37. Schuster, Lantermann ED (2004) Naturschutzstrategie: Lebensstiltypen II. Repräsentative Befragung zu Naturschutz, Lebensstilen sowie Einstellungen zum Naturschutz und naturschonenden Handeln. Projektbericht an das Bundesamt für Naturschutz. Universität Kassel oS.

38. Schuster K (2006) Lebensstile im Natursport. In: BfN (Hrsg) Natursport und Kommunikation. Tagungsband zum Internationalen Fachseminar, ErlebnisKonsumgut Natur: verehrt - verzehrt. BMU-Druckerei. Bonn-Bad Godesberg $22-29$

39. Bundesamt für Naturschutz/BfN/Hrsg (2006) Natursport und Kommunikation Tagungsband zum Internationalen Fachseminar, Erlebnis-Konsumgut Natur: verehrt - verzehrt, BMU-Druckerei. Bonn-Bad Godesberg. 95 S.

40. Dernbach B (2007) Journalismus und Nachhaltigkeit. Oder: Ist Sustainability Development ein attraktives Thema? In: Michelsen, Godemann J (Hrsg.) Handbuch Nachhaltigkeitskommunikation: Grundlagen und Praxis. Oekom, 2. Aufl. München: 184-193.

41. LifePR (2009) Neues TV Magazin: Eurosport For The Planet. Umweltschutz und Sport in einem paneuropäischen Magazin vereint. Pressemitteilung. 